\title{
Study Analysis of the Need for the Mobile Learning Model Learning Based on Problem Based Learning in Learning Citizenship Education in Senior High School
}

\author{
Khairil Anwar Uzir ${ }^{1}$, Sahat Siagian ${ }^{2}$, R. Mursid $^{3}$ \\ 1,2,3 Universitas Negeri Medan, Indonesia \\ Email: vennyribka85@gmail.com
}

\begin{abstract}
This study aims to analyze the needs of developing PBL-based mobile learning learning models. The study was conducted using a survey method of High Schools in the City of Pematang Siantar. The research subjects were 18 class teachers who taught Pancasila and Citizenship Education learning. The object being studied is the responses of school principals and teachers to the development of PBL-based mobile learning models, the tendency of teachers to apply PBL-based mobile learning models in schools, student reasoning, and student character. Data collected by interview, questionnaire, observation, and test. Data were analyzed descriptively. The analysis shows that (1) school principals have not yet fostered the development of PBL-based mobile learning learning models, so they support development efforts, (2) teachers have not yet developed and used PBL-based mobile learning learning models, so they support and declare readiness to be involved in the development, (3) learning models used by teachers so far there have been no indications leading to PBL-based mobile learning learning models.
\end{abstract}

Keywords: mobile learning; problem based learning

\section{Introduction}

The development of education that has been carried out since Indonesia's independence has produced quite impressive results so that in general the quality of Indonesian human resources is much better. However, compared to ASEAN countries, we are still far behind, therefore, more active efforts need to be increased so that our nation does not become an alien guest in their own country. (Utari et al., 2016).

Educators are an important component in education, because of its function as a facilitator in the ongoing teaching and learning activities. Therefore, educators and educators should have good competence, especially having innovative ideas in teaching. Because students need someone who can explore their potential, therefore educators and educators are required to be more innovative.(Vojta, 2010).

The ultimate goal of education is the realization of a social order marked by the existence of noble character in every individual and justice in the state in terms of life. Likewise with the aim of education in high school, schools are always required to refer to national education goals by taking into account the characteristic stages of student development; suitability of the environment and regional development needs; national development direction; and pay attention to the development of Science and Technology and human life globally. The objectives of senior secondary education are: (1). enhance students' knowledge to continue their education at a higher level and to develop themselves in line with the development of science and technology, (2). enhance the ability of students as members of the community in establishing reciprocal relationships with the surrounding social, cultural and natural environment.(Vojta, 2010). 
Pancasila and Citizenship Education are subjects aimed at educating students to foster morale and make citizens of good character, which is expected to be realized in daily life, both within the school environment and outside the school environment. Pancasila and Citizenship Education (Pancasila and Citizenship Education) was originally supposed to be able to shape the activeness, creativity, and intelligent thinking of students in solving any problems that existed by way of consensus agreement in accordance with the 4th-point Pancasila precepts namely "Democracy led by wisdom wisdom in deliberations and representation ". Pancasila and Citizenship Education is a lesson about government and citizens 'obligations relating to the state or between citizens'. (Sadono et al., 2014) defines Pancasila and Citizenship Education as follows: Educational programs or subjects that have the primary goal of educating students to be good, democratic and responsible citizens.

The Pancasila and Citizenship Education program views students in their position as citizens, so that the programs, competencies or materials provided to students are directed to prepare them to be able to live functionally as citizens and good citizens.(Setiawan, 2014) The learning function of Pancasila and Citizenship Education itself as a vehicle encourages activeness or participation and intelligent thinking by optimizing the creativity possessed by each student. Then the PPancasila and Citizenship Education subjects as a vehicle to form smart, skilled, and characterful citizens who are loyal to the nation and the State of Indonesia reflect themselves in the habit of thinking and acting in accordance with the mandate of the 1945 Constitution.

One of the goals is to provide an intelligent thinking competition that is critical thinking in every response to the issue. The role of the teacher is very important in creating an educated society, by changing the learning styles of students in the classroom. Now this lecture method cannot be used anymore in Pancasila and Citizenship Education subjects, because the method is no longer suitable especially for Pancasila and Citizenship Education subjects, the lecture method is so boring that students tend to be passive and feel bored with the one-way method. That is because teachers are less creative. Teachers rarely involve students in teaching and learning activities in the classroom. So, stimulation lack of these students so students can not express their creativity in teaching and learning activities. This one-way method tends to make students just memorize it without any real action (Akbal, 2016).

Easy access to information and technology will slowly displace the role of books, magazines and newspapers. This also indirectly will slightly offend the role of the teacher in the delivery of subject matter. Teachers who deliver material but never update the material will be left behind from the development of a rapidly developing science. For example, the rapid development of technology a student might know ahead of time compared to his teacher, when the student is always accessing the internet and looking for information continuously. From the example above we can see how the role of information is very important in the learning process.

The presence of the Internet has had a significant impact on the lives of humankind in various aspects and dimensions of life. The internet is one of the instruments in the era of globalization that has made this world transparent and connected very easily and quickly without knowing the boundaries of territoriality and nationality. Through the internet people can access information in various fields so easily. With the internet the learning method will be different from the traditional learning process which is characterized by face-to-face interaction between the teacher and students in the class. 
Along with the development of internet technology, the Mobile Learning model has begun to be developed, so studies and research are needed. The essence of Mobile Learning is a conventional form of learning as outlined in digital format through Android technology. Developing a learning model Mobile Learning does not merely present subject matter on the internet, but needs to be considered logically and holds the principles of learning. The design element also needs to be considered, students will be more comfortable in front of the internet when the material is simple, personal, fast and the important thing is there is an entertainment element (Mardhatillah, 2019)

Through the development of problem-based learning based Mobile Learning students can communicate with their teachers anytime and anywhere, and vice versa, teachers can connect with their students through electronic media (Mardhatillah, 2019). The nature of the communication can be closed between one student and the teacher or even together. Through Mobile Learning, it is possible for students and teachers to be able to learn even if they are not physically present in the classroom. Learning activities become very flexible, this is because the existence of communication tools have become part of human life, one of which is a cellphone or mobile phone. Cellphone or cellphone is one of the tools of communication which is ingrained in the community so that almost all people use it. Human needs will increase so as to encourage mobile manufacturers to develop advanced features that can attract the interest of the community, one of which is by developing OS (Operating System) (Wirdaningsih, 2017).

This has become one of the reasons for developing Mobile Learning in the learning process, where this learning model will become a reference when an educational institution or institution wants to develop the quality, quantity and scope of the education sector. With this development model students and teachers no longer always have to face-to-face, but the learning process can be done at any time and is always ongoing (Anzar, 2018).

Mobile learning is a learning strategy that involves the use of handheld and mobile technology.

The acquiring processes various information knowledge and skills through the use of mobile technology that results in a change in behavior from its users. The learning approach used in this study is in accordance with the 2013 curriculum which is the concept of a scientific approach including observing, asking, reasoning, trying, forming networks. The scientific approach to learning has criteria including (1) learning material based on facts or phenomena that can be explained with certain logic or reasoning, not limited to roughly, imaginary, legendary, or fairy tales; (2) Encourage and inspire students to be able to understand, apply, and develop rational and objective thinking patterns in responding to learning material; (3) Based on concepts, theories, and empirical facts that can be accounted for; and (4) Learning objectives are formulated in a simple and clear, but interesting system of presentation. Based on observations in several high schools (SMA) in Pematangsiantar City the majority of students already have a Smartphone with an Android OS so that it can be used for learning with mobile learning.

\section{Research Methods}

Research Development or Research and Development (R\&D) are currently one type of research that has been widely developed. Development research is one type of research that can be a liaison or breaker of the gap between basic research and applied research. Research Development or Research and Development (R\&D) (Borg \& Gall, 1983: 772) and continued experiments which are often interpreted as a process or steps to develop a new product or 
improve an existing product. What is meant by products in this context is not always in the form of hardware (books, modules, learning aids in classrooms and laboratories), but can also be software such as programs for data processing, learning in classrooms, libraries or laboratories, or models-education model, training learning, guidance, evaluation, management, etc.

The development model in this study goes through the stages of conceptual models, theoretical models, hypothetical models, and final models. Conceptual models are analytical models, which mention product components, analyze components in detail, and show the relationships between components to be developed. The theoretical model is a model that describes a framework that is based on relevant theories and is supported by empirical data. Hypothetical models are models that have received expert and practitioner input through focus group discussions (FGDs). The final model is a model that has been empirically tested. The place of research is in high schools in Pematangsiantar City. The determination of the location of research consists of 3 (three) high schools in different districts in Pemantang Siantar City consisting of:

1. SMA Negeri 2 Pematang Siantar Jl. Patuan Nagari, North Siantar District.

2. SMA 5 Pematangsiantar Jl. Medan Siantar Martoba District

3. SMA 6 Pematangsiantar Jl. Cadika No.15 Siantar Sitalasari District.

The population in this study was all high school students in Pematangsiantar City. Due to various considerations it is not possible for all populations; the study took three school population soups, namely class X students of SMA Negeri 2 Siantar Utara District, SMA Negeri 5 Siantar Martoba District, and SMA Negeri 6 Siantar Sitalasari District who were taught learning using the Mobile Learning learning model. based on problem base learning using Android media. As the object of this research is learning media, the scale of students' responses to learning media and student learning outcomes tests. Sampling is done by random sampling technique.

The sample used in this study were 6 Pematangsiantar Public High School students by treating Pancasila and Citizenship Education learning using problem-based learning based Mobile Learning models. High School 5 students with Civics learning treatment using Direct Instruction learning models and for testing the validity and reliability are SMA Negeri 2 Pematangsiantar students.

\section{Discussion}

Based on the results of the analysis of the needs of the questionnaire showed that learning material is still not smooth enough to be used, it can also be seen from the students' daily test scores, there are still $46 \%$ of students not yet finished learning. This is due to the absence of an appropriate learning model, and learning still uses the learning learning model of discussion, recording material, and conventional lectures. $90 \%$ of students have a high interest in learning, but students have not been well facilitated in their learning. So that $100 \%$ of students say that it is necessary to develop a car learning learning model.

Based on the results of the questionnaire analysis of the needs of teachers said that learning has been going well, there is already a laboratory, there are books even though only amounted to 1 so the teacher must record each time the meeting, the teacher has never developed their own learning module. The manual used is only a package book from the government. Students also tend to be monotonous with lectures, discussions and work on questions. Learning has not used an innovative and interesting learning model. So that 
teachers feel the need to develop mobile-based learning models.

Based on the results of questionnaire analysis of student and teacher responses, as well as seeing the cognitive learning outcomes of students it is necessary to develop a learning model. One alternative teacher can do to improve student learning processes with learning development. This model is used as reference material for students, which contains a variety of material that must be studied with various worksheets and learning activities.

\section{Conclusion}

Based on the results of the questionnaire analysis it can be concluded that the development of mobile learning-based learning is needed both by students and teachers, through this mobile learning-based learning model it is expected to create good and effective learning so that learning in the classroom can be more meaningful.

\section{References}

Anzar, S. F., \& Mardhatillah, M. (2018). Analisis Kesulitan Belajar Siswa Pada Pembelajaran Bahasa Indonesia di Kelas V SD Negeri 20 Meulaboh Kabupaten Aceh Barat Tahun Ajaran 2015/2016. Bina Gogik: Jurnal Ilmiah Pendidikan Guru Sekolah Dasar, 4(1).

Akbal, M. (2016). Pendidikan Kewarganegaraan Dalam Membangun Karakter Bangsa. Jurnal Pendidikan Ilmu-Ilmu Sosial, 1(1), 355-364.

Lubis, S., and Buana, R. 2020. The Influence of Technology and Information on Student's Behavior: a Case Study of SMA Negeri 1 of Pantai Cermin at Serdang Bedagai. Britain International of Humanities and Social Sciences (BIoHS) Journal (2): 523528.

Mardhatillah, S. M. S., Surjono, H. D., \& Muhtadi, A. (2019). Thematic Learning Based on Gender Equality and Value of Diversity to Strengthen Student National Character.

Mardhatillah, S. M. S., Verawati, V., Evianti, E., \& Pramuniati, I. (2019). Bahan Ajar Interaktif Berbasis Kearifan Lokal Melalui Pendekatan Saintifik pada Pembelajaran Bahasa Inggris. Genta Mulia: Jurnal Ilmiah Pendidikan, 10(1).

Sadono, M. Y., Masruri, M. S., Yogyakarta, U. N., Belajar, G., Sadono, M. Y., Masruri, M. S., \& Yogyakarta, U. N. (2014). Keefektifan Vct dalam Pembelajaran Sejarah untuk Meningkatkan Nilai Nasionalisme, Demokrasi, dan Multikultural. Jurnal Harmoni Sosial, 1(1), 71-82.

Setiawan, D. (2014). Jurnal Pendidikan Ilmu Sosial Pendidikan Kewarganegaraan Berbasis Karakter melalui Penerapan. Jurnal Pendidikan Ilmu Sosial, 6(2), 61-72. jurnal.unimed.ac.id/2012/index.php/jupiis/article/view/2285\%0A\%0A

Syakur, A., Sugirin., and Widiarni. 2020. The Effectiveness of English Learning Media through Google Classroom in Higher Education. Britain International of Linguistics, Arts andEducation (BIoLAE) Journal (2): 475-483.

Utari, U., Degeng, I. N. S., \& Akbar, S. (2016). Pembelajaran Tematik Berbasis Kearifan Lokal di Sekolah Dasar dalam Menghadapi Masyarakat Ekonomi Asean ( MEA ). Jurnal Teori dan Praksis Pembelajaran IPS, 1(1), 39-44.

Vojta, M. (2010). Characteristics of the Effective Leader. Nursing Outlook, 21(11), 721-723. http://www.ncbi.nlm.nih.gov/pubmed/12189123

Wirdaningsih, W., \& Mardhatillah, M. (2016). Penerapan Media Audio-Visual terhadap Keaktifan pada Materi Hubungan antara Sumber Daya Alam dengan Lingkungan Siswa Kelas IV SD Negeri Pasi Teungoh Kecamatan Kaway XVI. Bina Gogik: Jurnal Ilmiah Pendidikan Guru Sekolah Dasar, 3(2). 